\title{
Kallmann syndrome with Horse shoe kidney: A Case Report
}

\author{
Suman kotwal*, Akash Gandotra, JB singh, Ghanshyam Dev Gupta, Annil Mahajan \\ Govt. Medical college Jammu.
}

Submission: March 28, 2017; Published: May 02, 2017

*Corresponding author: Suman kotwal, Jammu University, H. no 55/1 sharika vihar, Roop nagar, Jammu, India, Tel: 9419087899;

Email: sumankk1230@rediffmail.com

\section{Introduction}

Kallmann syndrome (KS) isolfactogenital dysplasia resulting from agenesis or dysgenesis of the olfactory bulbsandis associated with hypogonadism due to defect in migration of gonadotropin releasing hormone $(\mathrm{GnRH})$ cells and olfactory nerve from their common origin in olfactory placode during early fetal life [1,2]. KS prevalence varies from 1 in 10,000 to 1 in 60,000 individuals andmay due to sporadic, X-linked recessive (XLR), autosomal dominant or as autosomal recessive modes of inheritance $[3,4]$. Many other anomalies like choanal atresia, cardiac abnormalities, renal abnormalities, mirror movements, hearing loss and colour bindness have been describedin patients with KS. Only few case reports in literature have described association of KS with horse shoe kidney. We illustrate a case of Kallman syndrome with horse shoe kidney.

\section{Case Report}

An 18 year male presented to our endocrine clinic because of the absence of pubertal development. He was born of non consanguineous marriage and full term normal spontaneous delivery. He has two siblings. Small sized penis was observed by parents at birth but did not seek any consultation till boy complained ofhaving small phallusand testisas compared to his peers. He had normal motor and mental milestones and intelligence was at par with age. He had no history of seizures, blurring of vision, colour blindness, hearing loss and mirror movements. On further inquiry he was having loss of sense of smell since birth.

On physical examination, his weight was $60 \mathrm{~kg}$, height was $168 \mathrm{~cm}$, arm span was $177 \mathrm{~cm}$, and with eunuchoid stature (upper segment to lower segment ratio was 0.78 ). He has high pitched voice. He had no axillary and pubic hair and facial hair were absent. He had bilateral descended prepubertal testes

measuring $2 \mathrm{ml}$ using the orchidometer and microphallus, with penile length of $3.5 \mathrm{~cm}$. There were no other abnormalities on systemic examination. Neurologic examination was essentially normal except for complete loss of sense of smell. Investigation revealed normal complete blood count, blood glucose, kidney function and liver function tests. Testosterone was $17.11 \mathrm{ng} /$ $\mathrm{dl}$, FSH $0.86 \mathrm{miu} / \mathrm{ml}, \mathrm{LH}<0.02 \mathrm{miu} / \mathrm{ml}$, thyroid function tests and prolactin was normal. Ultrasonography showed horse shoe kidney (Figure 1) and MRI showed olfactory bulb aplasia on both sides (Figure 2). Genetic study was not possible because of financial constrains.

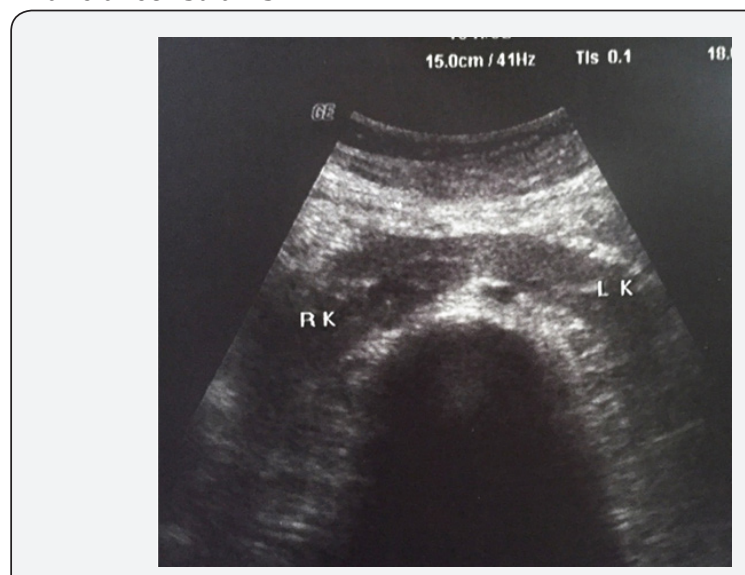

Figure 1: USG Showing horse shoe kidneys.

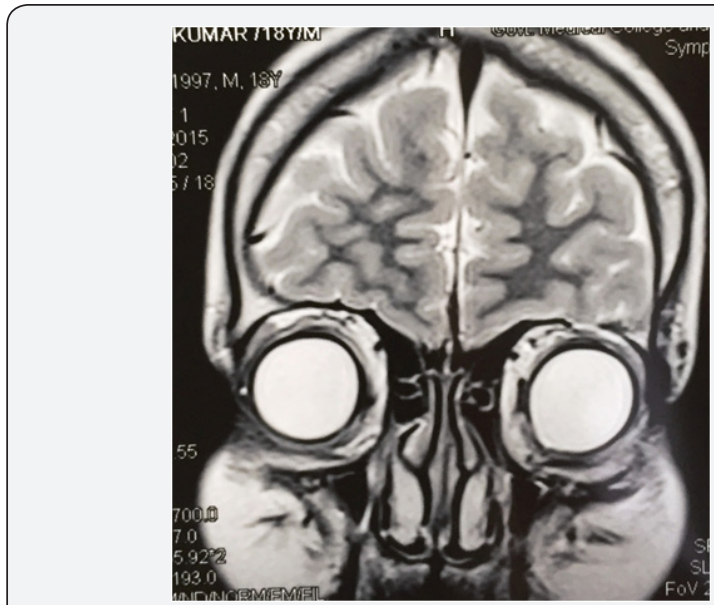

Figure 2: MRI: showing Aplasia of olfactory bulbs. 


\section{Discussion}

KS is characterised by hypogonadotropic hypogonadism and hyposmia or anosmia. It is a genetically heterogenous disorder,the most prevalent is an X-linked form that maps to the KAL1 gene [5]. A delay in pubertal development is the most common cause for affected patients to seek medical evaluation. Our patient presented with delayed puberty, characterised by high pitched voice, absence of facial and axillary hair andpubic hair, micropenis and bilateral small testes. Hormonal evaluation showed low FSH, low LH and low testosterone levels. Differential diagnosis will include KS, GnRH receptor mutation, GPR54 mutation, DAX-1 mutation and hypopituitarism [2].

The diagnosis of KS in this case was straightforward because of the hypogonadotropic hypogonadism in association with hyposmia and documented radiologic findings in MRI. Thediagnosis may be difficult to establish in patients of prepubertal age who may require both genetic testing and MRI [6]. Morphological abnormalities of olfactory apparatus in KS are best evaluated with MRI. Madan et al. [6] reported MRI findings of five male patients with clinical findings suggestive of KS syndrome. All patients had hypogonadotropic hypogonadism and anosmia.

A variety of urinary tract abnormalities have been reported in patients having KS, these include; unilateral or bilateral renal agenesis or hypoplasia, horseshoe kidney, bilateral VUR, duplication of the left ureter etc. [7-9]. KAL mutationshas been seen in number of patientswith KS and this gene is alsoexpressed in the mesonephros and metanephros duringembryonic developmentwhichsuggests that KAL plays a yet indeterminate role in kidney development $[10,11]$. Here we report a case of Kallmann syndrome with horse shoe kidney.

\section{Conclusion}

Several congenital anomalies are seen in patients with kallmann syndrome.Kallmann syndrome with horse shoe kidney has scarcely been reported.

\section{References}

1. Degroot L, Jameson JL (2006) Endocrinology. ( $5^{\text {th }}$ edn), Elsevier Saunders, Philadelphia, USA, 2006: 2847-2849.

2. De Bellis A, Sinisi AA, Conte M, Coronella C, Bellastella G, et al. (2007) Antipituitary antibodies against gonadotropin-secreting cells in adult male patients with apparently idiopathic hypogonadotropic hypogonadism. J Clin Endocrinol Metab 92(2): 604-607.

3. White BJ, Rogol AD, Brown KS, Lieblich JM, Rosen SW (1983) The syndrome of anosmia with hypogonadotropic hypogonadism; a genetic study of 18 new families and a review.Am J Med Genet 15(3): 417-435.

4. Dean JC, Johnston AW, Klopper AI (1990) Isolated hypogonadotropic hypogonadism: a family with autosomal dominantinheritance. Clin Endocrinol 32(3): 341-347.

5. SSEBhagavath B, Layman LC (2007) The genetics of hypogonadotropic hypogonadism. Semin Reprod Med 25(4): 272-286.

6. Madan R, Sawlani V, Gupta S, Phadke RV (2004) MRI findings in Kallmann syndrome. Neurol India 52(4): 501-503.

7. Martul P, Pineda J, Levilliers J, Vazquez JA, Rodriguez-Soriano J, et al. (1995) Hypogonadotrophic hypogonadism with hyposmia, X-linked ichthyosis and renal malformation syndrome. Clin Endocrinol (Oxf) 42(2): 121-128.

8. Wegenke JD, Uehling DT, Wear JB, Gordon ES, Bargman JG, et al. (1975) Familial Kallmann syndrome with unilateral renal aplasia. Clin Genet 7(5): 368-381.

9. Bick DP, Schorderet DF, Price PA, Campbell L, Huff RW, et al. (1992) Prenatal diagnosis and investigation of a fetus with chondrodysplasia punctata, ichthyosis, and Kallmann syndrome due to an Xp deletion. Prenat Diagn 12(1): 19-29.

10. Kirk JMW, Grant DB, Besser GM, Shalet S, Quinton R, et al. (1994) Unilateral renal aplasia in X-linked Kallmann's syndrome. Clin Genet 46(3): 260-262.

11. Duke VM, Winyard PJD, Thorogood P, Soothill P, Bouloux, et al. (1995) $\mathrm{KAL}$, a gene mutated in Kallmann's syndrome, is expressed in the first trimester of human development. Mol Cell Endocrinol 110(1-2): 73-79.
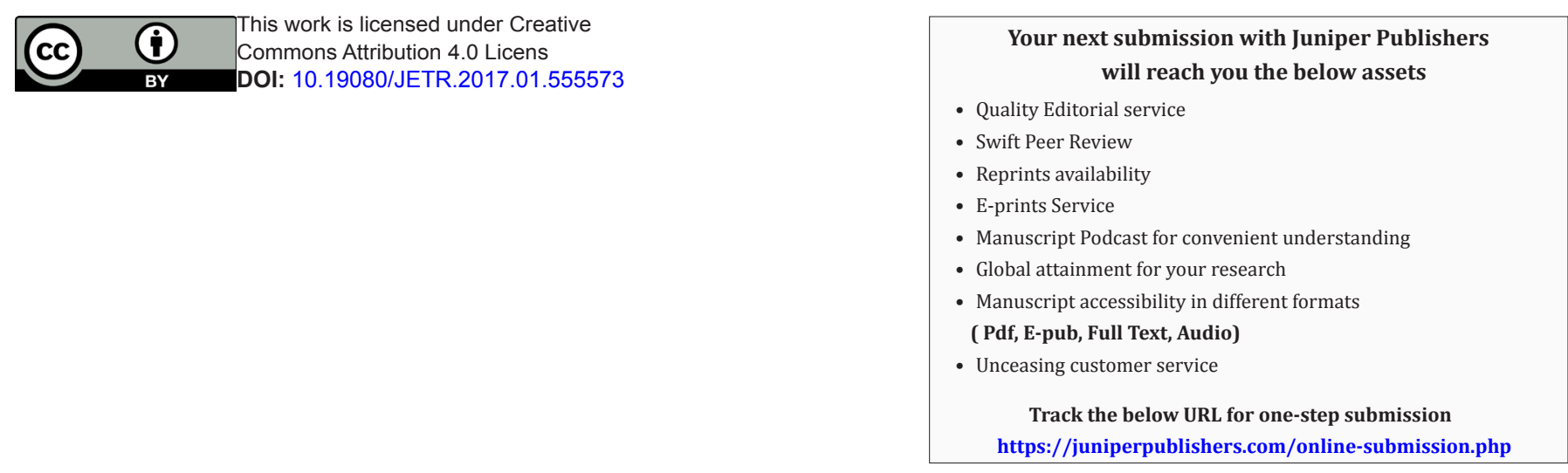